\section{Review of Ph.D Studies in Humanities: Updating New Horizons in Education}

\section{Abstract}

The context of information society, technological development and new societal challenges demands new frameworks for critical analysis of the knowledge production as well as for the geopolitical democratization of their distribution. In our article "Cultural processes, social change and new horizons in education," published in Procedia. Social and Behavioral Sciences, 174, we presented the educational development work done in the Doctorate in Creation and Culture Studies of the Universidad de las Américas Puebla (UDLAP), Mexico, in order to face the contemporary demands for understanding and studying processes of knowledge construction, transmission and diffusion beyond the academicstandards of use and epistemologies of text. This focus has been especially important for the program, as it is based on the collaboration on the transdisciplinary basis between Arts and Humanities and Social Sciences, having some extensions to ITC engineering and Natural Sciences through its research projects and creative practices. This text is a review of the above-mentioned article but also an updating of that program presentation due to the recent curriculum renovation and with it, integration of new research foci.

Keywords: Psychology; Political sciences; Anthropology; Humanities; Natural sciences

\section{Anne Kristiina Kurjenoja* and lleana Azor Hernández}

Doctorate in Creation and Culture Studies, Universidad de las Américas Puebla (UDLAP), Mexico

\section{*Corresponding author: \\ Anne Kristiina Kurjenoja \\ ” annek.kurjenoja@udlap.mx}

Associate Professor, Department of Architecture, Universidad de las Américas Puebla (UDLAP), Mexico.

Tel: (222)2292000

Citation: Kurjenoja AK (2018) Review of Ph.D Studies in Humanities: Updating New Horizons in Education. Acta Psychopathol Vol.4 No.2:11

Received: March 26, 2018; Accepted: April 12, 2018; Published: April 28, 2018

\section{Introduction}

One of the characteristics of the new Ph.D. programs in humanities has been their trend to widen the Eurocentric shallow sense of history, seeking for knowledges sprung from the unseen roots of the Others forgotten by the historical amnesia of the Western universities [1,2]. The response to that has been the emergence of programs with 'disobedient' epistemic frameworks; the colonial axis of power-knowledge-culture, which had reduced entire people to objects of study, and others to hegemonic producers of knowledge, had now to be re-valued by themselves by socialcultural struggle and by epistemological and aesthetic innovation [3].

In the case of high level research, knowledge production and doctoral education, challenges we are continuously facing are complex, beginning with the need to understand the social tendencies of the contexts in which we are working as well as the usability and impact of the produced knowledge in the contemporary societies and how new forms of knowledge production should be inserted to institutionalized structures such as universities. Thus, in order to contribute to the alternative practices in knowledge production in communities of emergent economies such as Mexico, since 2006 the Universidad de las Américas Puebla (UDLAP) has offered a transdisciplinary doctorate program in Creation and Culture Studies with the participation of a wide range of researchers from art, architecture and urban studies to anthropology, political sciences and psychology. This recently revised and re-accredited program by the National Council for Science and Technology, CONACYT, has maintained its unusual pedagogical focus through the insertion of students to institutional research projects and scaffolding their academic performance through research groups thus consolidating the basic goals of collaboration of the program:

Unusual pedagogical approach through this tutorial system provides scaffolding by faculty together with a whole group of associated researchers and fellow students, detonate a high level, trans-disciplinary research in order to detect, explore and potentiate alternative knowledges as vehicles to lead to a social change and to a socio-culturally sustainable development, 
as detonators of cultural practices and knowledge production beyond the Occidental canon [1].

\section{Transdisciplinarity and Education for Development in Ph.D. Studies in Humanities}

In the academic world, the intellectual authority has been evidenced through high quality research validated by institutionalized systems and practices as gatekeepers for the knowledge production, through different categories of academically validated products. Results of the research work should though also have an impact beyond the academic circles, in wider social contexts through concrete indicators of their viability and usability as knowledge. In the ideal case, these external indicators should match the consensus reached during the critical disciplinary debate inside the academic circles [4].

In order to have an effective focus on the current societal problems and demands for development in emergent economies, the trans-disciplinary institutional research project accompanying the Ph.D. program has constructed its line of thought and that of knowledge production, on the postcolonial and postmodern socio-cultural basis aimed to nurture the postgraduate program. The institutional research project itself, to which the dissertation work of each student has been inserted and through which it has been constantly monitored, has resulted an innovative pedagogic mechanism through which students have been involved in active research work guided by an academic tutor and thus effectively introduced to research methodologies and theories straight from the beginning [1].

In the program framework, the student is not only a qualified researcher, but also a social innovator, creator and experimenter, being an interpreter and transmitter of socially constructed knowledge gathered through the interaction between students and human communities. The cooperation between researchers, creators and communities in terms of recollection, analysis and study of alternative knowledge production requires a special kind of creativity and sensibility able to capture meanings and individual and collective manifestations as these present forms beyond the canonical validation of knowledge by cultural norms. Thus, these hybrid, sensuous and critically reflective cultural forms demand new, innovative research initiatives that challenge the current stiff university system demanding substantial changes in the traditional role of research and education in humanities; for example, Belonging Bologna-seminar report [5] emphasizes that art, design and culture education and research should always be connected to and reflecting the events of the outside world [1].

Taking into account the above-mentioned observations, the Ph.D. program in Creation and Culture Theories proposes to introduce its students to the incredible whirl of social, political, scientific and artistic events worldwide considering that the velocity of these events has exceeded our capacity to elaborate responsible theoretic reflection, to understand their origin and causes and their impact and future consequences in societies. Thus, the analysis of cultural production has been exceeded by modes of action, thinking and feeling not known before; the wideness and velocity of the cybernetic web, the scope of technology of mass media and the human environment manipulated by commercial strategies and the recent collapse of paradigms that until today had given form to the individual and to the collective creativity and innovation, demands for a formation of researchers and creators who are able to respond and give consistence to our time proposing spaces for cultural dialogue and critique and new forms for creative knowledge production and transmission [6].

\section{Program Updates and Renewed Research Lines}

To reach these goals, in Arts and Humanities research and education it has been especially critical to be able to define what 'viability' and 'usability' of knowledge mean. Though, in Humanities as in other areas related to creative processes with non-rational foci, the criteria of legitimation of knowledge is changing, thanks to the transdisciplinary collaboration. The study of different experiences of alternative knowledge production and new creative practices related to spatial and sensorial interventions, performances, experimentation with materials, has been managed in the Doctorate in Creation and Cultural Studies and in the institutional research project 'Epistemologies beyond the Text. Cultural Practices in the Information Age' linked to it through research lines 'Expanded Scriptures' focused mainly on ITC and new media in art, culture and society, and 'Subaltern Knowledges' focused on the study of the subaltern Others on the postcolonial basis. As examples the results, some dissertation projects can be mentioned, such as 'The Theatre of the Oppressed: An Aesthetic Practice Where the Subject Becomes Visible' [7], in which Theatre of the Oppressed (TO) of Augusto Boal [8] was used as the main methodology applied to explore through theatre and in creative ways some daily expressions of patriarchate, homo/lesbophobia, employment discrimination and even power relations existing in prison between internals beyond the control of the wards; 'Which Reality? Interactions at the Southern Border of Mexico, as a Projection of an Artistic Creation Practice' [9], aimed to be at the same time a creation process and an analysis of an artistic practice as a vehicle for generating and understanding knowledge [10] based on the diversity of cultural and social manifestations along the southern border of Mexico, where the border line not only marks a geopolitical limit between two nation-states (Mexico and Guatemala), but also emphasizes their differences and all they have in common through a palpable repertoires of mobility of people, things and events [11], and 'Behind the Walls: Democracy, Political and Cultural Management in Mexico and Ecuador 2007-2013' [12] exploring cultural management, democratization, cultural policy and cultural democracy [13] as concepts that shape practices of street art and graffiti as non-hegemonic experiences in institutional spaces and in which the author suggests that both street art and graffiti should be considered beyond their traditional location as part of youth culture and their relation with gangs and urban criminality [1].

In 2016-2017, due to the request of the National Council for Science and Technology, CONACYT, and its National Postgraduate 
Programs of Excellence, the Ph.D. program was critically analyzed and renovated to respond to the current conditions in the area of Latin American doctoral education. Thus, the program is defining itself now as a program immersed in current lines of thought worldwide in order to be an authentic school for contemporary thinking and as a leader in the formation of new generations of thinkers, creators, promoters, analysts and opinion leaders able to understand and enhance the present conditions having the multiple and heterogeneous areas as the platform for the cultural production [6].

The renovated and reinforced program is aiming at educating researchers and creators able to trigger cultural and societal innovations that permit to rethink contemporary culture through critical creative practices and knowledge production with a guaranteed influence on diverse socio-cultural environments through interdisciplinary dialogue in which socio-cultural knowledge is used to analyze objects of study from different perspectives [6]. In order to follow the past successful framework of an institutional research project as an all covering umbrella for all the studies of the program, a new research framework initiative is under work. The proposed topic for this projects is defined as "Technologies of Knowledge, Globalization and New Cultural Practices,' exploring expanded epistemologies with in order to study transformations in the knowledge formats, their usability and viability in the globalizing contexts and the specific conditions in which these transformations are manifesting themselves and diffused worldwide due to the demand for constructing, transmitting but also for manipulating, possessing and controlling new knowledge and creative and innovative practices. Graduate studies impact several disciplines to improve the environment and influence a change in the society in which they develop. Researchers, professors and graduates develop new ideas on artistic and cultural approaches: graffiti as a cultural form of resistance [12] and the philosophical categories of insignificant or the non-interrupting strategy of repetition and passivity that reveals new approaches on cultural, social and political resistances [14]. Others like posthegemony and everyday life are also forms of cultural resistance that help draw the necessary social changes [15].

The renovated program and this new initiative is divided into three research lines and research groups denominated 'Art, technology and knowledge' focusing on the study of the current art theory that involves the creator and art researcher to discussions of their socio-cultural environment impacted by technological practices of the knowledge production. The line 'Globalizations, governability and mobility' explores the knowledge production in terms of the analysis of forms of governability manipulating us but also manipulated by us. Through these framework topics such as Nation-state, global cities, bio-and necro-politics, open government and 'fluent planning' may be explored. And finally, the line 'Intersectionalities: gender, bodies and spaces' propose to analyze the complexity of the world and of the human experience focusing on the study of discrimination, injustice and identities. Covered by these three frameworks, new dissertation projects have been or are being developed. On the other hand, migratory movements from Latin America to the United States and Canada have triggered interesting transcultural situations in which local expressions and identities have been transported to new places beyond nation borders impacting the culture of places of destination of the migrants, as has happened in the case of 'chicanos', Mexican origin people in the United States. The Ph.D. dissertation project entitled 'Mexican Digital Diaspora: Transnationalism, ICT and Social Networks in North America' [16], explores new perspectives and paradigms about transnationalism within the Mexican migration context. Taking into account transnationalism that consists of those processes forged by migrants through which they maintain simultaneous and complex social relations between their locations of origin and their current place of living [17], the project explores the migrant users' performativity in Internet and particularly the increasing use of Social Networks (like Facebook or Twitter). Specifically, in the area of health, this epistemological vision influence in modifying the natural history of the disease in various pathologies that afflict Third World countries. For example: "Illegality", Flexible Accumulation and Health: Return Migration of Sick, Exhausted and Dying Workers; Society for Applied Anthropology is one of the approaches that allow us to recommend migratory public policies that affect a better quality of life and socio-political development [18].

The new hybrid cultures do not only emerge in the new living places of the migrants but also have a transformative effect in their communities of origin, triggering cultural and social transformations, in ways of life and popular culture. We should also mention the dissertation project 'The Burdens of Chastity' [19], studying the clashes between the LGBT communities and the society in Mexico and projects still under work such as 'Biopolitics and Dirty War in Mexico: Construction of Precarious Subjectivities' about the political conflict between the government and diverse resistance movements during the socio-political turbulences in Mexico in 1960's, when disappearances and political murders were the vehicle for the government to maintain under control the anti-governmental movements impacting the subjectivities of the period $[20,21]$.

\section{Conclusion}

It is important to continue highlighting our intention to follow what Water Mignolo has pointed out about the knowledge production and transmission of knowledge as vehicles in the peace making and construction of identity in the postcolonial Latin America as a geopolitical project. Thus, the contemporary higher education and research carried out in the emerging economies of the previous colonies such as Mexico should be able to develop an amplified potential to produce updated knowledge beyond traditional institutions of knowledge construction and epistemological production. Countries like Mexico, aspiring of occupying a much stronger and visible participation to the international politics and culture, needs to trigger a societal change in its own territory in order to solve its great inequalities. In this task all the creative, cultural, historical and human resources should be used including research and project development. As we have demonstrated, new kind of research projects in which 
different disciplines have joined their forces in order to explore a wide range of problematic of our globalizing world on the local level, can go beyond their accustomed limits in order to impact local conditions through locally adapted knowledge production. It is important to create solutions and strategical models for the transformation of social realities in conflictive places through recognizable languages and meanings, be they textual or nontextual, in order to reformulate the socio-cultural identities transforming them to detonators of the societal change through culturally sustainable processes. Thus, transdisciplinary research and postgraduate education produces researchers, creators, teachers and socio-cultural promoters dedicated to the study of how the globalization, technology and cultural processes define the knowledge production processes as well as the character of our postmodern knowledge and of the institutions and institutional connections and networks that manipulate and operate it.

\section{References}

1 Kurjenoja AK, Azor Hernández I (2015) Cultural processes social change and new horizons in education. Procedia Soc Behav Sci 174: 3405-3412.

2 Elkins J (2014) Artists with PhDs: On the new doctoral degree in studio art. $2^{\text {nd }}$ edn. Washington D.C., New Academia Publishing, p: 498.

3 Steyerl H (2010) Aesthetics of resistance? Artistic research as discipline and conflict. Mahkuzine, 8, Utrecht School of Arts, Faculty of Visual Arts and Design, pp: 31-37.

4 Biggs I (2006) Art as research, doctoral education, and the politics of knowledge. Reader, Visual Art Practice. Bristol, University of the West England, p: 1-8.

5 http://www.mahku.nl/download/maHKUzine08_web.pdf

6 http://www.udlap.mx/ofertaacademica/Default. aspx?cveCarrera=DCT

7 Fernández L (2010) El teatro del oprimido: Una práctica estética donde el sujeto se hace visible. Ph.D. Dissertation Thesis. Mexico, Fundación Universidad de las Américas, Puebla (UDLAP).

8 Boal A (2006) The aesthetics of the oppressed. Routledge: USACanada 49: 125-127.

9 Garza MQ (2012) Which reality? Interactions at the south border of Mexico as a projection of an artistic creation practice. Ph.D. Dissertation Thesis. Mexico, Fundación Universidad de las Américas, Puebla (UDLAP).

10 Maffesoli M (1997) Elogio de la razón sensible, una visión intuitiva del mundo contemporáneo. Buenos Aires: Paidós Studio.

11 Negri A, Coco G (2006) Global: Biopoder y luchas en una América Latina globalizada. Buenos Aires: Paidós, p: 244.

12 López MF (2014) Detrás de los muros. Democracia, política y gestión
Retaking once again the words of Walter Mignolo, as in our article in Procedia, Social and Behavioral Sciences, we continue reaffirming:

And I say the 'humanities,' and not just 'the humanists' [...] Since all the knowledge and understanding is human understanding (from genomics to dance, from electric engineering to literature, from mathematical models in economy to political economy), every scholar, academic, and scientist has a responsibility towards the humanities; in other words, he or she has critical, ethical, and political responsibilities in the production, dissemination, transformation, and enactment of knowledge. The humanities can no longer afford to be what they have been for the past sixty years: a 'complement' to the 'efficiency' of 'serious' technological knowledge that guarantees a constant progress of humanity as a whole and a sublime 'enrichment' of human beings as Human Being.

cultural en México y Ecuador 2007-2013. Ph.D. Dissertation Thesis. Mexico, Fundación Universidad de las Américas, Puebla (UDLAP).

13 Mouffe C (2007) Prácticas artísticas y democracia agonística. Barcelona: Museu d Art Contemporani de Barcelo, p: 72.

14 Grijalva L (2016) The Political potential of repetition and melancholia: Thinking social transformation in the radicalization of Ernesto Laclau's subject position. Ph.D. Dissertation Thesis. Mexico, Fundación Universidad de las Américas, Puebla (UDLAP).

15 Fonseca V (2018) La revolución vegana: Análisis posthegemónico de movimiento vegano en Puebla. Ph.D. Dissertation Thesis in process. Mexico, Fundación Universidad de las Américas, Puebla (UDLAP).

16 Meza Rodríguez E (2017) Diápora digital mexicana: Transnacionalismo, ICT y Redes Sociales en Norteamérica. Ph.D. Dissertation Thesis. Mexico, Fundación Universidad de las Américas, Puebla (UDLAP).

17 Schiller NG, Basch L, Szanton Blanc C (1995) From immigrant to transmigrant: Theorizing transnational migration. Anthropol $Q 68$ : 48-63.

18 Lee AE, Sabo S (2015) The spillover of U.S. immigration policy on citizens and permanent residents of Mexican descent: How internalizing "illegality" impacts public health in the borderlands. Front Public Health 3: 155.

19 Gómez Rossi AAR (2016) The burdens of chastity. Ph.D. Dissertation Thesis. Mexico, Fundación Universidad de las Américas, Puebla (UDLAP)

20 Sánchez Hernández AL (2018) Biopolítica y guerra sucia en México: Construcción de subjetividades precarias. Ph.D. Dissertation Thesis in process. Mexico, Fundación Universidad de las Américas, Puebla (UDLAP).

21 Mignolo W (2003) Globalization and the geopolitics of knowledge: The role of the humanities in the Corporate University. Nepantla: Views from South 4: 97-119. 